J. Asiat. Soc. Bangladesh, Sci. 45(1): 55-69, June, 2019

\title{
IMPACTS AND CHALLENGES ASSOCIATED WITH SHRIMP CULTIVATION IN PARULIA UNION, SATKHIRA, BANGLADESH: AN EMPIRICAL STUDY
}

\author{
SHAMIMA PRODHAN*, BIVUTI BHUSHAN SIKDER AND MAHBUBA NASREEN \\ Institute of Disaster Management and Vulnerability Studies, \\ University of Dhaka, Dhaka-1000, Bangladesh
}

\begin{abstract}
This paper offers an overview of an empirical study conducted at Parulia union in Satkhira district, Bangladesh on unplanned shrimp culture, practiced by masses that ultimately led to serious environmental degradation and socioeconomic consequences such as salinity intrusion, decline in water and soil qualities, reduction in agricultural productions, decrease in cattle production, migration, and human health hazards. The real scenarios give evidences of the impacts of imposed shrimp cultivation and the associated challenges faced by the communities including reduction in cultivable land area $(59.8 \%)$, increase of Gher area $(48.0 \%)$, increase of soil salinity $(74.5 \%)$, reduction in vegetable production $(67.6 \%)$, reduction in agriculture farming $(67.6 \%)$, reduction in freshwater fish culture $(63.7 \%)$, impacts on livelihood patterns and reduction in local varieties of crops, fruit trees, and plants. Major challenges identified by the respondents are: reduction in soil quality $(41.2 \%)$, reduction in water quality $(38.2 \%)$, social problems $(20.6 \%)$, problems in getting safe drinking water $(19.6 \%)$, landlessness $(35.3 \%)$, migration $(34.4 \%)$, outbreak of common diseases (19.6\%) etc. Urgency of a national policy framework addressing the issue holistically is of grave importance to solve the problem.
\end{abstract}

Key words: Impact, Shrimp cultivation, Salinity intrusion, Environmental degradation

\section{Introduction}

Shrimp (Penaeus monodon) culture was mainstreamed in Bangladesh since 1970s (Rahman and Hossain 2013). The "Gher" farming system has been well suited to shrimp (Paul and Vogl 2011, Rahman et al. 2011) and salinity found to be linked with shrimp and considered to be a major challenge in coastal areas of Bangladesh (Hossain et al. 2012, Uddin and Haque 2010). Nearly $27 \%$ of arable land in the southwestern coast is affected by salinity. In recent decades, the development of commercialized shrimp farming has fueled substantial national and international debate concerning its overall unpropitious ecological and socioeconomic consequences (Islam 2008, Kabir et al. 2016, Saha 2017). With the change of time, shrimp farming has grown as one of the major industries in Bangladesh contributing to the national economy (Deb 1998) as cultured

*Author for correspondence: <shamimaprodhan07@gmail.com> 
shrimp is considered one of the most demandable seafood products worldwide (Alam et al. 2005). The spectacular rise of the demand of brackish water shrimp in international market has stimulated the interests of its mass production in Bangladesh. At present, the industry has experienced a good deal of horizontal expansion and spread across the entire coastal belt (Azad et al. 2009, Swapan and Gavin 2011). An SRDI (2010) study underscores that salinity affected area has increased from 0.833 million hectares in 1973 to 1.056 million hectares in 2009. Recent salinity level in Satkhira district stipulates that $43 \%$ of the total salinity affected area has been incapacitated for agricultural production (Rabbani et al. 2013). Scientific studies over decades suggest that shrimp culture has, however, significant impacts on soil, environment, physiography, agriculture, ecosystems, economy, demography, public health, and other important socioeconomic factors (Bailey 1988, Hopkins et al. 1995, Páez-Osuna 2001, Primavera 2006, Ali 2006, Kabir and Eva 2014, Akber et al. 2017). There are also claims that it has led to disintegration of economic and social conditions of coastal rural communities (Ali 2004). Paul and Røskaft (2013) reported environmental degradation and loss of traditional agriculture due to shrimp culture. Arrangements for shrimp cultivation have reduced the availability of grazing land too and troubled local livestock. Increasing soil salinity and corresponding disruptions have emerged as one of the biggest threats to agricultural productivities (Payo et al. 2017, Clarke et al. 2015, Dasgupta et al. 2015). In the studied area, production of staple fruit trees such as jackfruit, date, mango, plums have also been reduced gradually. Water salinity exceeds the expected level that is required for fish production, and thereby threatens freshwater fisheries. It has also been reported that logging of saline water into fresh land degrades soil quality and adversely affects local vegetation, plants and trees, crops, fishes, livestock, environment, and public health (Khan et al. 2011). A feasible legal framework sustained by actionable policies could be of practical help for sustainability (Afroz and Alam 2013). The present study is an attempt to reflect on how unplanned development of shrimp aquaculture in the coastal areas of Bangladesh entailed significant impacts and drawbacks. The specific objectives of the study are as follows:

(i) To identify the impacts of water and soil salinity on agriculture farming and local varieties of crops, vegetables, fruit trees, and plants;

(ii) To understand the impacts of water salinity on freshwater fisheries, aquatic resources, and the impacts of soil salinity on livestock and poultry;

(iii) To assess how livelihood patterns of the local community have been changed due to salinity issues and

(iv) To perceive various other challenges faced by the local community of Parulia union. 


\section{Materials and Methods}

A variable-based procedure was adopted in order to assess the impacts and challenges invited by commercialized shrimp cultivation practices at Parulia union, Debhata Upazila of Satkhira district (Map 1). A mixed method comprising both quantitative and qualitative approaches was employed and this empirical process required a span of at least three months. Quantitative approach includes a field survey with a structured questionnaire which was carried out in 2014 in 12 villages of Parulia union (Map 1), namely Chaltetola, Kholisakhali, Rangashishe, Koikhali, Polgadarchawk, Norarchawk, Chauddogram, Chhotosanta, Gucchogram, Patakhali, Uttar Parulia, and Dakshin Parulia. Several important criteria were considered during the selection of the fields of study which involved: (a) Areas that had been heavily exploited for commercialized shrimp cultivation, (b) areas still dependent on traditional agriculture, (c) places that encountered significant environmental degradation based on prior scientific literatures and local people's experiences and (d) locals that faced socioeconomic changes due to shrimp culture. From 12 villages, indicative of shrimp culture concentration, 102 households $(\mathrm{HH})$ were selected randomly to be able to reflect the overall scenarios. While selecting the households, senior members of the family (living in those areas for more than 20 years), who were associated with shrimp farming, traditional agriculture, wage earning, day labor, and/or other low-income occupations and had experiences of the problems were considered. Socioeconomic and demographic characteristics of the respondents were also considered. A good number of women were also selected to address gender issues.

The qualitative data were collected through different tools and techniques. Four FGDs were done with farmers and community people following snowball sampling. The selection procedures for FGDs depended on people who somehow experienced the impacts of shrimp culture; also, the people who were associated with other agricultural patterns for a comparison. The locations were besides shrimp farms, open land near households to suit convenience for the participants. Ten KIIs were conducted at different locations with experts following purposive sampling techniques which include key government policymakers, district agriculture extension officers who execute various projects, and NGO executives. Two case studies were conducted too. Keen observation of the researchers also played a role. Apart, authoritative and widely cited peer-reviewed scholarly journal articles from recent scientific studies, books, documents, proceedings of conferences, and presented papers have also been reviewed as a source of secondary data. Table 1 shows some of the sociodemographic characteristics of Parulia union. 


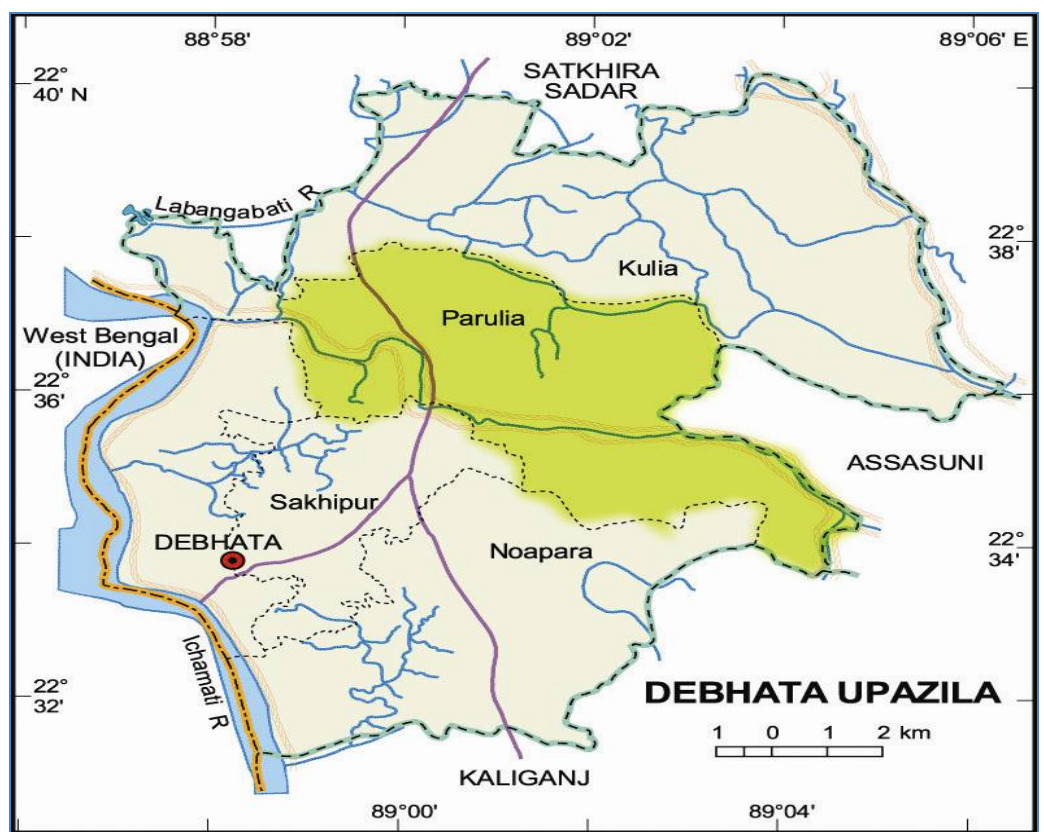

Map 1. Map showing study area (Parulia union); Source: Banglapedia, 2013.

Table 1. Sociodemographic information of Parulia union.

\begin{tabular}{ll}
\hline & \multicolumn{1}{c}{ Parulia union } \\
\hline Union: Parulia & Children under age of five: 484 \\
Upazila: Debhata & Literacy rate: $55.66 \%$ \\
District: Satkhira & Principle crop: Paddy and shrimp and fish \\
Area: $44 \mathrm{~km}^{2}$ & River: 1 (Ichamoti) \\
Village: 27 & Khal: 2 \\
Households: 5752 & Beel: 10 \\
Population: 34867 & Water salinity (normal): $0-22 \mathrm{ppt}$ \\
Male: 17785 & Water salinity (in winter): $2-4 \mathrm{ppt}$ \\
Female: 17082 & Soil salinity (maximize in summer): $4-12 \mathrm{ppt}$ \\
\hline
\end{tabular}

Source: Development planning 2013-14, Parulia union Parishad, Debhata, Satkhira

\section{Results and Discussion}

Paul and Røskaft (2013) reported environmental degradation and loss of traditional agriculture due to shrimp culture. As shrimp farming has been expanding significantly, respondents in the study area have identified sorts of variations in their locality over more 
than last 40 years. Majority of the respondents has mentioned that they have observed substantial reduction of crop yields $(90.3 \%)$ and freshwater fisheries (80.6\%). In addition, they have noted some remarkable changes in vegetable production (61.1\%), livestock ranching (51.4\%), and homestead gardening (23.6\%) in their locality (Fig. 1).

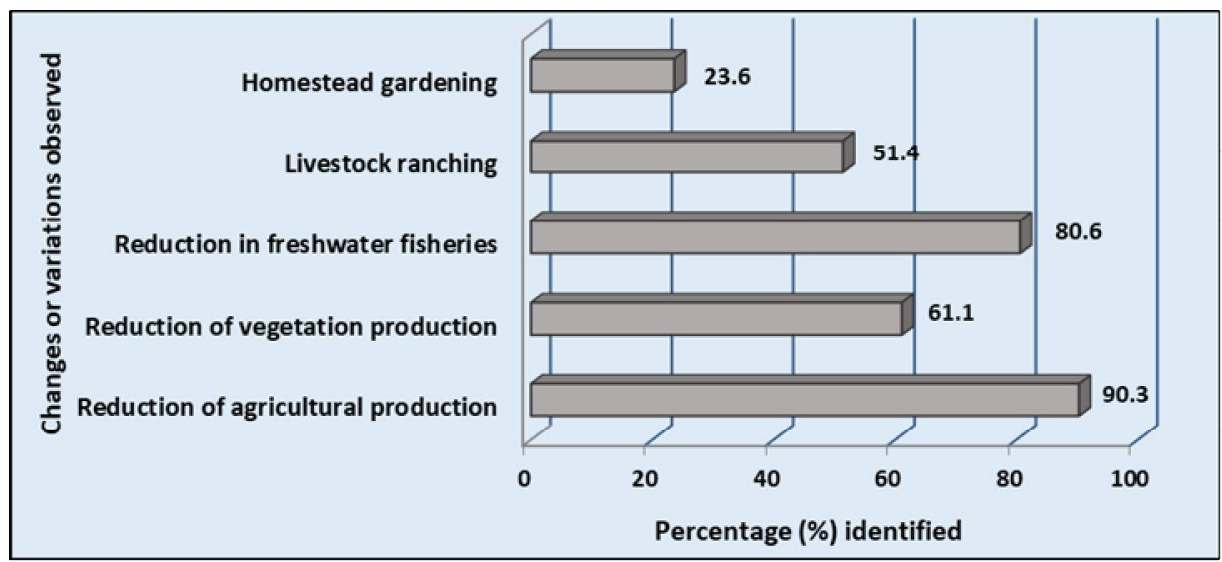

Fig. 1. Variations or changes identified by the respondents in the study area.

The socioeconomic vulnerabilities of the study area have been exacerbated by unplanned shrimp cultivation (Islam et al. 2012, Rahman et al. 2013). The percentage of cultivable land has decreased significantly and average number of lands occupied by shrimp farm has increased steadily since the introduction of shrimp cultivation. Since its introduction, shrimp farming has been expanding significantly and respondents in the study area have identified various impacts and challenges as charted in Table 2. Farmers have emphatically noted that due to the availability of saline water, they become more interested in shrimp cultivation in a Gher as it is instantly financially gratifying and that has given rise to the number of Ghers dramatically, eventually reducing traditional agricultural land. Moreover, due to the intrusion of saline water into Ghers, level of soil salinity is also increasing $(74.5 \%)$ day by day and reducing crop yields. Besides, reduction in vegetable production (67.6\%), traditional agriculture farming (67.6\%), and reduction in freshwater aquaculture $(63.7 \%$ ) have also been identified as major impacts in this area (Table 2). Similarly, reduction of soil and water quality (41.2 and 38.2\%), landlessness (35.3\%), and migration (34.4\%) are some of the major challenges identified (Table 2). Some (20.6\%) of the respondents especially the landless and marginalized groups have stipulated that they have suffered various environmental, economic, socio-demographic, and other problems which are undesirable. Shrimp cultivation in the locality has 
worsened the states of livelihood and deepens the problems whereas the qualities of life are impacted gradually. Some (19.6\%) of the respondents from marginalized group specifically the people from Norarchawk, Chaltetola and Rangashishe villages expressed that due to inroads of saline water, they have been suffering from various gastrointestinal diseases such as diarrhea, dysentery, stomach ache, digestive disorders etc. People of these villages are to travel miles to fetch pure fresh drinking water and sometimes suffer from dehydration.

Table 2. Impacts and challenges associated with shrimp cultivation in the study area identified by the respondents.

\begin{tabular}{lcc}
\hline \multirow{2}{*}{ Impacts } & \multicolumn{2}{c}{ Response } \\
\cline { 2 - 3 } & Frequency $(\mathrm{N})$ & Percentage $(\%)$ \\
\hline Reduction of land area & 61 & 59.8 \\
Increase of gher area & 49 & 48.0 \\
Increase in soil salinity & 76 & 74.5 \\
Vegetable production & 69 & 67.6 \\
Agriculture farming & 69 & 67.6 \\
Fresh water fish culture & 65 & 63.7 \\
Challenges & & \\
Soil quality & 42 & 41.2 \\
Water quality & 39 & 38.2 \\
Social problem & 21 & 20.6 \\
Problems in safe drinking water & 20 & 19.6 \\
Landlessness & 36 & 35.3 \\
Migration & 35 & 34.4 \\
Outbreak of public disease & 20 & 19.6 \\
\hline
\end{tabular}

Adapted from: Field study, 2014; N = 102 (multiple frequency).

Disappearance of many local fruit trees and plant varieties have also been observed in this locality. According to respondents, yields from sweet fruit varieties such as mango, papaya, and jackfruits are on the decrease. Similarly, salinity tolerant plants such as Koroi, Gewa, Golpata etc. which are more common in the Sundarbans, gradually replacing the local plant varieties. Some of the commonly found plant and fish varieties which have replaced local varieties in the study area are listed below:

Common plant varieties in the study area: Koroi (Albizia sp.), Gewa (Excoecaria agallocha), Golpata (Nypa fruticans), Babla (Acacia nilotica), Date palm (Phoenix sylvestris), Sopheda (Achras sapota), Taal (Borassus flabellifer), Coconut (Cocos nucifera), Shimul (Bombax ceiba), and different types of cactus. 
Common fish varieties in the study area: Tilapia (Oreochromis mossambicus), Pangas (Pangasius pangasius), Nunatengra (Mystus gulio), Kurkhullo/Mudskipper (Apocryptes bato), Rohu (Labeo rohita), Mrigel (Cirrhinus cirrhosus), Silver carp (Hypophthalmichthys molitrix), Japanese punti (Puntius sp), Phasa/Phaissa/Gangetic hairfin anchovy (Setipinna phasa) etc.

\section{Major impacts of shrimp cultivation in Parulia union and their implications}

Some of the major impacts identified in the studied area due to expansion of shrimp farming are discussed below:

Impacts on agricultural farming: It has been found that two seasons are most feasible for the farmers to cultivate paddy in a year viz. from (a) February - May and (b) June November. The percentage of Boro production was found to be highest at 46.1 before and at present it is 45 (Table 3). Though farmers used to cultivate local (indigenous) Boro varieties previously, but presently they have started cultivating hybrid and high yielding paddy varieties (HYV) such as Jamaibabu 10, BIRI 28, Chini Kanai, Akhter 6, Tejdhan, Hira etc., as local varieties are not able to withstand excessive soil salinity in this area. In the period June - November, farmers also cultivate Aman together with jute. As hybrid varieties for Aman are not so available, farmers, therefore depend on salinity tolerant and high yielding Boro varieties. Also, as Boro takes less time for yields (120 - 125 days), farmers in this area are more interested in cultivating these varieties in comparison to Aman where it takes longer (140-145 days). From FGDs, it has been found that Aman is mainly cultivated in high plains such as in Uttar (North) and Dakshin (South) Parulia where soil salinity is much lower, crop production in these two villages are also higher than other villages of the study area. In addition, all the paddy varieties such as Aus, Aman, and Boro are cultivated in Dakshin Parulia. But in Uttar Parulia, Boro and mustard production remains at its highest. Paddy is not cultivated in eastern part of Parulia, but in smaller scale, it is still being cultivated with shallow and deep tube well water in the western part of the study area.

Impacts on agricultural crops, vegetables, fruit trees, and plants: From the survey and observation, it has been found that some local crop varieties are not cultivated nowadays in the study area as their production has been significantly reduced due to high level of soil salinity. Crops such as paddy, mustard, sesame, Kheshari were once very common and their production was also very high in Parulia union. Most of the crop varieties are now somewhat threatened as their production has reduced gradually. Table 4 shows some threatened crop varieties viz., vegetables (74.5\%), paddy (59.8\%), and fruits $(43.1 \%)$. However, potato $(28.4 \%)$, sesame $(24.5 \%)$, mustard $(15.7 \%)$, jute $(15.7 \%)$, various 
varieties of pulses such as Arahar (7.8\%), Khesari (27.5\%) are also identified as "kind of threatened".

Table 3. Crop cultivation periods and types of identified by the respondents in the study area.

\begin{tabular}{|c|c|c|c|c|}
\hline \multicolumn{5}{|c|}{ Periods and types of crop cultivation by the respondent farmers } \\
\hline & \multirow[t]{2}{*}{ Period } & \multicolumn{2}{|c|}{ Response } & \multirow[t]{2}{*}{ Crops } \\
\hline & & $\begin{array}{l}\text { Frequency } \\
(\mathrm{N})\end{array}$ & $\begin{array}{l}\text { Percentage } \\
(\%)\end{array}$ & \\
\hline \multirow[t]{5}{*}{ Before } & November-March & 13 & 12.7 & $\begin{array}{l}\text { Robi crop (mustard, potato, } \\
\text { onion, vegetables) }\end{array}$ \\
\hline & February-May & 47 & 46.1 & Paddy (Boro) \\
\hline & June-November & 39 & 38.2 & Paddy, Jute (Aman) \\
\hline & April-September & 3 & 2.9 & Paddy $(A u s)$ \\
\hline & Total & 102 & 100 & ---- \\
\hline \multirow[t]{5}{*}{ Present } & November-March & 11 & 13.8 & $\begin{array}{l}\text { Robi crop (mustard, potato, } \\
\text { onion, vegetables) }\end{array}$ \\
\hline & February-May & 36 & 45 & Paddy (Boro/Hybrid) \\
\hline & June-November & 29 & 36.3 & Paddy (Aman), Jute \\
\hline & April-September & 4 & 5 & Paddy (Aus/Hybrid) \\
\hline & Total & 80 & 100 & ----- \\
\hline
\end{tabular}

Adapted from: Field study, 2014; N = 102 (multiple frequency).

Table 4. Threatened local crop varieties identified by the respondents.

\begin{tabular}{lcc}
\hline \multirow{2}{*}{$\begin{array}{l}\text { Threatened crops identified by } \\
\text { the respondents }\end{array}$} & \multicolumn{2}{c}{ Response } \\
\cline { 2 - 3 } Paddy & Frequency $(\mathrm{N})$ & Percentage $(\%)$ \\
Wheat & 61 & 59.8 \\
Mustard & 7 & 6.9 \\
Maize & 16 & 15.7 \\
Tobacco & 4 & 3.9 \\
Arahar & 4 & 3.9 \\
Sesame & 8 & 7.8 \\
Khesari & 25 & 24.5 \\
Jute & 28 & 27.5 \\
Fruits (mango, litchi, coconut & 16 & 15.7 \\
etc.) & 44 & 43.1 \\
Potato & 29 & 28.4 \\
Onion & 5 & 4.9 \\
Vegetables & 76 & 74.5 \\
\hline
\end{tabular}

Adapted from: Field study, 2014; N = 102 (multiple frequency). 
Figs 2 and 3, respectively present lists of vegetables and fruit trees in the study area of which some are critically threatened, some nearing disappearance, and some are at a level of near-extinction. Whereas others are in the stage of near extinction. Fig. 2 shows that vegetable spinach $(6.5 \%)$, celery (5.6\%), basil (2.8\%), and arum (2.8\%) ranked high in terms of extinction whereas fruits like mango (12\%) ranked high in terms of extinction followed by blackberry (7.4\%), jujube (4.6\%), guava (3.7\%), banana (3.7\%) etc. (Fig. 3).

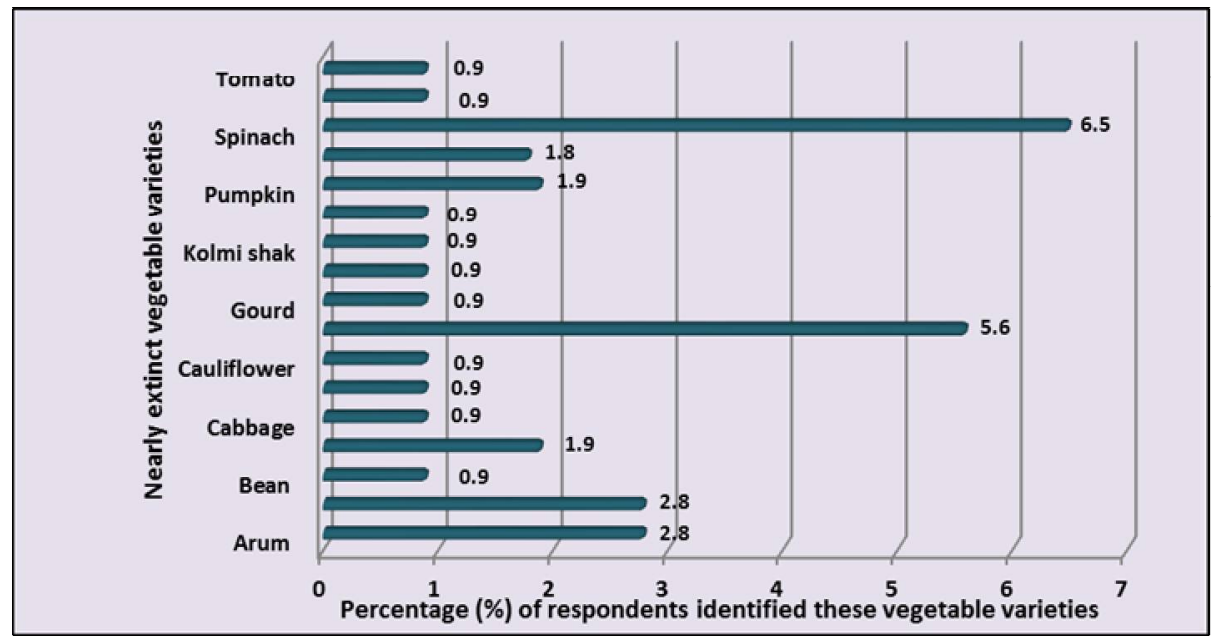

Fig. 2. Nearly extinct vegetable varieties identified by the respondents.

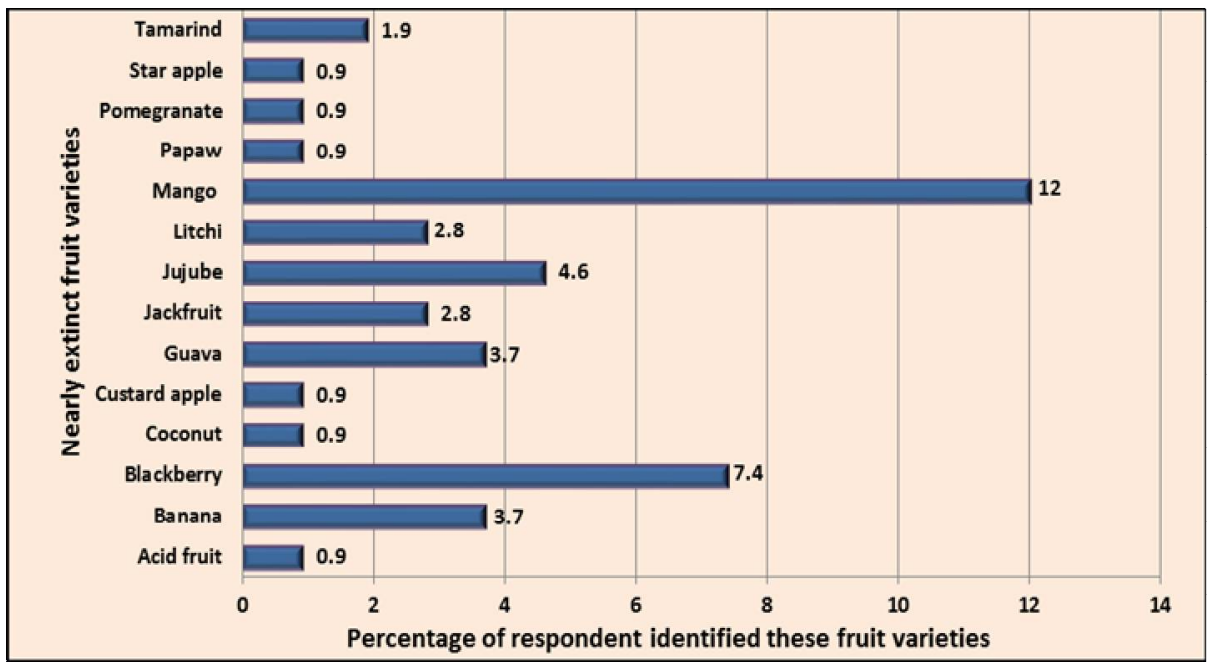

Fig. 3. Nearly extinct fruit varieties identified by the respondents. 
Impacts of water salinity on freshwater fisheries: Hundreds of the ponds once used for freshwater fish cultivation are now converted to gher in the study area, resulting in increased water salinity which is not favorable for many of the traditional/local fish varieties such as Koi (Anabas testudineus), Bele (Periophthalmodon schlosseri), Catla (Catla catla) etc. are likely to decrease day by day. To meet the demands of local animal protein, farmers in this locality are now cultivating salinity tolerant mono-sex Tilapia, Vetki (Coral), Phaisa, Kurkhullo etc. fishes together with shrimp. From the findings of present study, it is assumed that freshwater fishery is going through a very critical stage. Fishes like Koi, catfish, wallago, snake-headed Murrel, and Bele (Gobi) are affected most by water salinity with percentages of 15.7, 12.7, 7.84, 6.86, 6.86, respectively (Fig. 4).

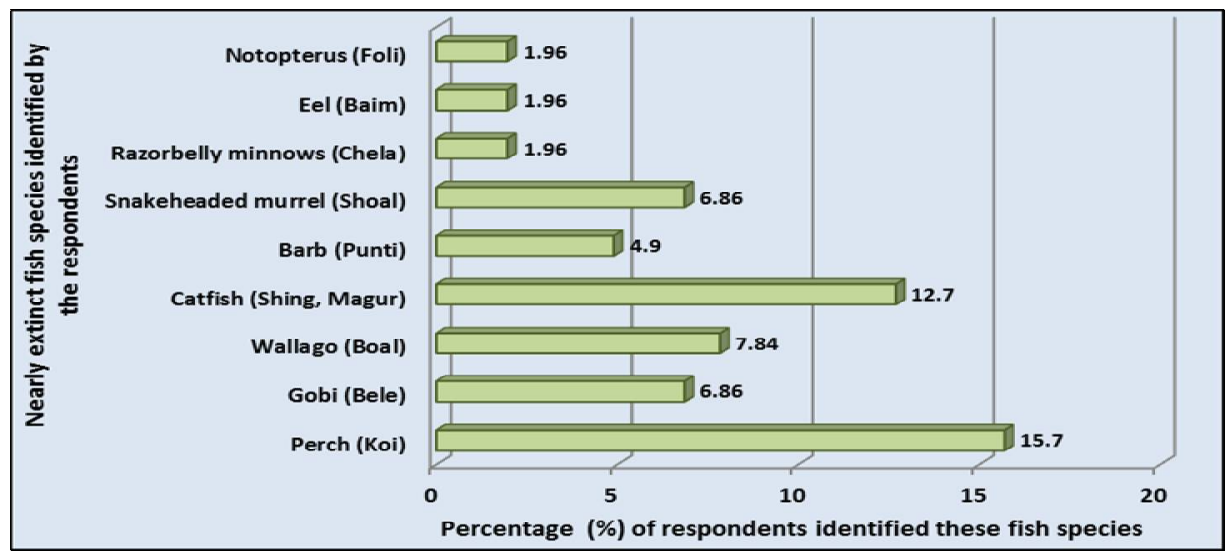

Fig. 4. Nearly extinct fish varieties identified by the respondents.

Impacts of soil salinity on livestock and poultry: It has been found that livestock ranching is experiencing diminution in Parulia union. Population of domestic animals such as cows, buffaloes, goats, and poultry are decreasing with the increase of shrimp cultivation. Reasons for the reduction of domestic animals are most likely to be attributed to scarcity of grass, straw, grazing lands, non-availability of pure drinking water, and poor living conditions. Respondents have mentioned that one bundle of "Khar" or "hay" costs BDT 80 which is beyond their affordability. The unavailability of shapla grass which was once very common in their locality and considered as staples for cows, buffaloes, and goats is now almost disappeared due to increase of soil salinity. Decrease of grazing lands as a result of shrimp culture expansion is another important reason of livestock disappearance in the study area. Therefore, it has been suggested that the unplanned expansion of 
shrimp ghers paved ways for reducing grazing land for cattle and subsequently reduced the number of livestock.

Impacts on livelihood patterns: Impacts of salinity on crop production have already been discussed. Most of the respondents have already experienced drastic yield reductions that forced farmers to change their occupation. Maximum people of the study area were engaged in agriculture (98\%) and livestock ranching (72.5\%) whereas presently most of them consider shrimp farming as their main livelihood activities (95.1\%) (Table 5). Some (32.4\%) are also found to be engaged in shrimp farm as day labor, a shifting livelihood option from agriculture day labor. Freshwater fish cultivation in this area is also reduced from 8.82 to $1.0 \%$ as a result of increased water salinity. Table 5 compares occupational changes among respondents and changing patterns of livelihoods in the study area.

Table 5. Different traditional and new occupations identified by the respondents in the study area.

\begin{tabular}{llllll}
\hline \multirow{2}{*}{ Occupation } & \multicolumn{2}{l}{ Traditional occupation } & & \multicolumn{2}{c}{ New occupation } \\
\cline { 2 - 3 } \cline { 5 - 6 } & $\begin{array}{l}\text { Frequency } \\
(\mathrm{N})\end{array}$ & $\begin{array}{l}\text { Percentage } \\
(\%)\end{array}$ & & $\begin{array}{l}\text { Frequency } \\
(\mathrm{N})\end{array}$ & Percentage \\
\hline Agriculture & 100 & 98 & & 2 & 1.96 \\
Shrimp farming & 4 & 3.9 & & 97 & 95.1 \\
Livestock ranching & 74 & 72.5 & & 3 & 2.9 \\
Small business & 20 & 19.6 & & 4 & 3.9 \\
Agricultural day labour & 28 & 27.5 & & 4 & 3.9 \\
Shrimp farming day labour & 1 & 1.0 & & 33 & 32.4 \\
Homestead gardening & 8 & 7.8 & & 2 & 1.96 \\
Fresh water fisheries & 9 & 8.82 & & 1 & 1.0 \\
Others & 0 & 0 & & 2 & 1.96 \\
(Govt. service, madrasa teacher etc. $)$ & & & & \\
\hline
\end{tabular}

Adapted from: Field study, 2014; N = 102 (multiple frequency).

\section{Challenges associated with shrimp cultivation in Parulia union}

Lack of fresh drinking water and public health: Study findings indicate that salinization of domestic and agricultural water supplies are main problems in Parulia union. In a Focus Group Discussion (FGD) of Norarchawk village, participants have mentioned, due to introduction of shrimp cultivation people have severely been troubled with the dearth of safe drinking water. They have also suffered from various gastrointestinal problems such as diarrhea, dysentery, and irritable bowel syndrome (IBS) after using perilous water from nearby ponds and canals which are highly contaminated by salinity. People of this village need to walk considerable distances to fetch pure drinking water as they do not 
afford deep tube well. Respondents also confirmed that sometimes they even do not have enough safe water for taking a bath as most of the water bodies have been converted to ghers. By bathing in local waters, they are attracting various skin diseases.

Landlessness and migration: The village Norarchawk is resided by a good number of marginalized people where most of them are landless. Landless people are gradually shifting to different cities during the months of January to April when there are apparently no income opportunities in their own localities. Not only the landless but the gher owners also move to other cities for additional income. From the Focus Group Discussion (FGD), it has been revealed that after releasing shrimp fry into the gher, it takes three months to harvest; during this period, the farmers move out to other cities or in the neighboring country for additional income. Reportedly, they move to Dhaka, Chittagong, Bandarban, Khagrachhari, Tamil Nadu (India), Bihar (India), and Mumbai (India). In the migrating cities, they work in construction sites, brick kilns, and factories as they lack other skills or any alternative income generating source such as small business, grocery shops etc. Therefore, they left their localities for extra income and to ensure food security.

Socioeconomic problems: Respondents (20.6\%) have identified specific social problems such as further marginalization of farmers, violations of human rights, internal chaos, and gender inequality are found to have been triggered. Though farmers work hard but they do not enjoy the benefits much gained by shrimp farming; as a result, the poor become even poorer and that led them to migrate in other cities. This has continuously fueled other socioeconomic challenges like land ownership, food insecurity, income inequality, and landlessness. Children turnout at primary education centers has also lowered.

\section{Recommendations and Conclusion}

Therefore, considering the urgency of the above-portrayed scenarios, to guarantee sustainable agriculture with economic progress of the stakeholders, our recommendations would, however, be: (i) to revise the agriculture patterns holistically, (ii) to re-strategize shrimp farming processes, and (iii) to facilitate the farmers with any technological, technical, and monetary support necessary. Getting the farmers back to traditional agricultural patterns could be an option. Local agricultural department funded by the government should subsidize the transitional farming tenures and provide technical supports to the affected farmers to bounce back. Strengthening local community by ensuring food security can help us achieve the UN SDGs. 
Finally, Parulia holds the highest shrimp production niche presently in Debhata Upazila (sub-district) in Satkhira. Exploring the impacts of shrimp cultivation on agriculture and environment, socioeconomic dispositions, reduction in fruits and vegetable production, and livestock ranching, it can be stated that shrimp farming needs to be refurbished. This study unveils various implications and challenges that might have a far-reaching socioeconomic consequence. Most significant and persistent challenges faced by the community are mainly economic, environmental, social, demographic, health, and of soil and landlessness. The possibilities of wheat, mustard, and vegetables have also declined gradually and ultimately downgrading the socioeconomic basis of the community. However, some of the respondents have conceded that they do not want to be involved in shrimp farming anymore, for it does not bring any visible long-term benefits to them. Farmers in the study area expect that government would take necessary steps by facilitating proper drainage system and other relevant techniques so that they can start their traditional agriculture culture again.

\section{References}

Afroz, T. and S. Alam. 2013. Sustainable shrimp farming in Bangladesh: A quest for an integrated coastal zone management. Ocean \& Coastal Management, 71: 275-283.

Akber, M. A., M. A. Islam, M. Ahmed, M. M. Rahman and M. R. Rahman. 2017. Changes of shrimp farming in southwest coastal Bangladesh. Aquaculture International, 25(5): 18831899.

Alam, S. N., C. K. Lin, A. Yakupitiyage, H. Demaine and M. J. Phillips. 2005. Compliance of Bangladesh shrimp culture with FAO code of conduct for responsible fisheries: A development challenge. Ocean \& Coastal Management, 48(2): 177-188.

Alam, S. N., B. Pokrant, A. Yakupitiyage and M. J. Phillips. 2007. Economic returns of diseaseaffected extensive shrimp farming in southwest Bangladesh. Aquaculture International, 15(5): 363-370.

Ali, A. M. S. 2004. Technological change in agriculture and land degradation in Bangladesh: A case study. Land Degradation and Development, 15(3): 283-298.

Ali, A. M. S. 2006. Rice to shrimp: Land use/land cover changes and soil degradation in Southwestern Bangladesh. Land Use Policy, 23(4): 421-435.

Bailey, C. 1988. The social consequences of tropical shrimp mariculture development. Ocean and Shoreline Management, 11(1): 31-44.

Clarke, D., S. Williams, M. Jahiruddin, K. Parks and M. Salehin. 2015. Projections of on-farm salinity in coastal Bangladesh. Environmental Science: Processes \& Impacts, 17(6): 11271136.

Dasgupta, S., M. M. Hossain, M. Huq and D. Wheeler. 2015. Climate change and soil salinity: The case of coastal Bangladesh. Ambio, 44(8): 815-826.

Deb, A. K. 1998. Fake blue revolution: Environmental and socio-economic impacts of shrimp culture in the coastal areas of Bangladesh. Ocean \& Coastal Management, 41(1): 63-88. 
Hopkins, J. S., P. A. Sandifer, M. R. DeVoe, A. F. Holland, C. L. Browdy and A. D. Stokes. 1995. Environmental impacts of shrimp farming with special reference to the situation in the continental United States. Estuaries, 18(1): 25-42.

Hossain, M. L., M. K. Hossain, M. A. Salam and A. Rubaiyat. 2012. Seasonal variation of soil salinity in coastal areas of Bangladesh. International Journal of Environmental Science, Management and Engineering Research, 1(4): 172-178.

Hossain, M. S., M. J. Uddin and A. N. M. Fakhruddin. 2013. Impacts of shrimp farming on the coastal environment of Bangladesh and approach for management. Reviews in Environmental Science and Bio/Technology, 12(3): 313-332.

Islam, A. F. M. T., Navera, U. K. and Mahboob, M. G. 2012. Impact of brackish water shrimp farming on agricultural land and surrounding environment in the southwest coastal zone of Bangladesh. Proc. of the Intl. Conf. on Env. Asp. of Bang., 2: 11-19

Islam, M. S. 2008. From pond to plate: Towards a twin-driven commodity chain in Bangladesh shrimp aquaculture. Food Policy, 33(3): 209-223.

Kabir, M. H. and I. J. Eva. 2014. Environmental impacts of shrimp aquaculture: The case of Chandipur village at Debhata upazila of Satkhira district, Bangladesh. Journal of the Asiatic Society of Bangladesh, Science, 40(1): 107-119.

Kabir, M. J., R. Cramb, M. Alauddin and C. Roth. 2016. Farming adaptation to environmental change in coastal Bangladesh: Shrimp culture versus crop diversification. Environment, Development and Sustainability, 18(4): 1195-1216.

Karim, M. R. 2006. Brackish-water shrimp cultivation threatens permanent damage to coastal agriculture in Bangladesh. In: C. T. Hoanh, T. P. Tuong, J. W. Gowing and B. Hardy (Eds.), Environment and livelihoods in tropical coastal zones: Managing agriculture-fisheryaquaculture conflict. Wallingford, UK: CABI, pp. 61-71.

Khan, A. E., A. Ireson, S. Kovats, S. K. Mojumder, A. Khusru, A. Rahman and P. Vineis. 2011. Drinking water salinity and maternal health in coastal Bangladesh: Implications of climate change. Environmental Health Perspectives, 119(9): 1328-1332.

Páez-Osuna, F. 2001. The environmental impact of shrimp aquaculture: A global perspective. Environmental Pollution, 112(2): 229-231.

Paul, A. K. and E. Røskaft. 2013. Environmental degradation and loss of traditional agriculture as two causes of conflicts in shrimp farming in the southwestern coastal Bangladesh: Present status and probable solutions. Ocean \& Coastal Management, 85(A): 19-28.

Paul, B. G. and C. R. Vogl. 2011. Impacts of shrimp farming in Bangladesh: Challenges and alternatives. Ocean \& Coastal Management, 54(3): 201-211.

Payo, A., A. N. Lázár, D. Clarke, R. J. Nicholls, L. Bricheno, S. Mashfiqus and A. Haque. 2017. Modeling daily soil salinity dynamics in response to agricultural and environmental changes in coastal Bangladesh. Earth's Future, 5(5): 495-514.

Primavera, J. 2006. Overcoming the impacts of aquaculture on the coastal zone. Ocean \& Coastal Management, 49(9-10): 531-545.

Rabbani, G., A. Rahman, K. Mainuddin and I. J. Shoef. 2013. Loss and Damage from salinity intrusion in Satkhira District, coastal Bangladesh. Loss and Damage in Vulnerable Countries Initiative, Case Study Report. Bonn: United Nations University Institute for Environment and Human Security, pp. 8-10.

Rahman, M. M., V. R. Giedraitis, L. S. Lieberman, M. T. Akhtar and V. Taminskienè. 2013. Shrimp cultivation with water salinity in Bangladesh: The implications of an ecological model. Universal Journal of Public Health, 1(3): 131-142.

Rahman, M. M. and M. M. Hossain. 2013. Production and export of shrimp of Bangladesh: Problems and prospects. Progressive Agriculture, 20(1-2): 163-171. 
Impacts and challenges associated with shrimp cultivation

Rahman, S., B. K. Barmon and N. Ahmed. 2011. Diversification economies and efficiencies in a 'blue-green revolution' combination: A case study of prawn-carp-rice farming in the 'gher' system in Bangladesh. Aquaculture International, 19(4): 665-682.

Saha, S. K. 2017. Socio-economic and environmental impacts of shrimp farming in the southwestern coastal region of Bangladesh. International Journal of Research on Land-use Sustainability, 3(1): 128-137.

SRDI (Soil Resource Development Institute). 2010. Saline soils of Bangladesh. Retrieved from http://srdi.portal.gov.bd/sites/default/files/files/srdi.portal.gov.bd/publications/bc598e7a_df21 _49ee_882e_0302c974015f/Soil\%20salinity\%20report-Nov\%202010.pdf. p.5

Swapan, M. S. H. and M. Gavin. 2011. A desert in the delta: Participatory assessment of changing livelihoods induced by commercial shrimp farming in Southwest Bangladesh. Ocean \& Coastal Management, 54(1): 45-54.

Uddin, M. N. and A. Haque. 2010. Salinity response in southwest coastal region of Bangladesh due to hydraulic and hydrologic parameters. International Journal of Sustainable Agricultural Technology, 6(3): 1-7.

(Revised copy received on 04.04.2019) 